POLIIICAL ECONOMY RESEARCH INSTIIUIE

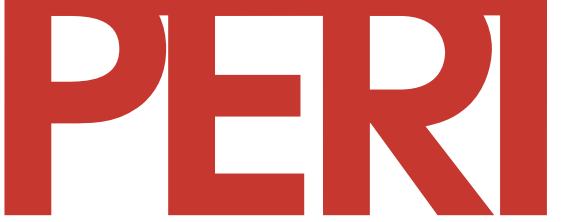

University of Massachusetts Amherst

\title{
International Environmental Justice: Building the Natural Assets of the World's Poor
}

Krista Harper and S. Ravi Rajan

2004

Gordon Hall

418 N. Pleasant St, Suite A Amherst, MA, 01002-1735 Telephone: (413) 545-6355 Facsimile: (413) 577-0261 Email:peri@peri.umass.edu Website:

http://www.umass.edu/peri/

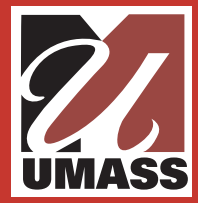




\title{
INTERNATIONAL ENVIRONMENTAL JUSTICE: Building the Natural Assets of the World's Poor
}

\section{Krista Harper and S. Ravi Rajan}

University of Massachusetts, Amherst and University of California, Santa Cruz

\author{
August 2004 \\ Revised version of a paper presented at \\ the International Conference on Natural Assets, \\ Tagaytay City, Philippines, January 2003.
}

\begin{abstract}
In recent years, vibrant social movements have emerged across the world to fight for environmental justice - for more equitable access to natural resources and environmental quality, including clean air and water. In seeking to build community rights to natural assets, these initiatives seek to advance simultaneously the goals of environmental protection and poverty reduction. This paper sketches the contours of struggles for environmental justice within and among countries, and illustrates with examples primarily drawn from countries of the global South and the former Soviet bloc.
\end{abstract}




\section{Introduction}

Across the globe, vibrant social movements are emerging that link issues of resource access, social security, environmental risks, and disaster vulnerability. Although everyone suffers the effects of pollution, global warming, and resource exploitation, poor people are especially vulnerable since they live closer to the margin of survival and are less able to afford cushions from environmental ills. At the same time, poor communities often face disproportionately heavy burdens from environmental degradation. Increasingly, low-income urban and rural communities around the world are organizing to fight for environmental justice - that is, for more equitable access to natural resources and environmental quality, including clean air and water. These new environmental movements connect sources and sinks; North and South; ecology and equity; and asset building and hazard vulnerability. They have begun to articulate new ideas about the quality of life, and about the meaning of development and modernization.

Environmental pollution and natural resource degradation are not simply 'quality of life' issues primarily of concern to middle-class people in the global North. In cities of both the North and the South, it is often the residents of poor neighborhoods who are most exposed to air fouled by car exhaust, diesel fumes, and deliberate and accidental industrial emissions. As urban growth accelerates, poor neighborhoods struggle for access to green space, public transportation, sanitation, and clean water and air. And in rural areas, it is the poor who are most dependent on natural resources from fisheries and forests, to rivers and rangelands, and the same time least able to protect them from despoliation.

There are three main reasons why poor communities often are affected disproportionately by pollution and environmental degradation:

- Siting: Poor neighborhoods are more likely to have environmental hazards and pollution dumped on them, especially if their residents belong to historically disenfranchised racial or ethnic groups (Bullard 1994).

- 'Move-in': In some instances, the poor are lured or compelled by economic circumstances to move to more polluted or degraded areas where property values are lower, a process sometimes called 'market dynamics' (Been 1994).

- Vulnerability: Even if exposure to environmental hazards were the same across the entire population, the poor would be at greater risk by virtue of their inferior access to good nutrition, health care, insurance, and private amenities such as bottled water and air conditioning (Boyce 2000).

This paper sketches the contours of what can be described as the international 'environmental justice' movement that has risen in response to these challenges. We begin by examining the dimensions of environmental inequity across countries, between the nations of the global South and North. We then consider environmental injustice within countries of the South. ${ }^{1}$ We do not attempt to be comprehensive, but instead use examples to draw out some common features of environmental justice dramas being played out across the globe. In particular, we explore the relationship between environmental injustice and the social attributes of class, race, ethnicity, age, and gender. Against this backdrop, we explore what communities across the world are doing 
to combat environmental contamination and resource depletion, and how these efforts to reclaim and restore natural assets are helping to redefine the meaning of environmentalism.

\section{The Environment and Inequality among Countries}

Environmental inequalities exist between the industrialized countries of the 'global North' and the developing countries of the 'global South'. Many countries of the former 'Second World' (eastern Europe and the former Soviet Union) face environmental threats similar to those in the global South. The global North exploits the environments of poorer countries in three main ways:

- as a source of raw materials;

- $\quad$ as a sink where the North can dispose of wastes and engage in polluting activities; and

- through coercive conservation that aims to preserve wild ecosystems and biodiversity, with little or no consideration for the human communities living in or near these protected areas.

The South as 'Source': Minerals Extraction and Agribusiness

Since the beginning of colonialism, Asia, Africa, and the Americas were seen by the colonizers as a source of natural wealth to be exploited for short-term gains. Although the European explorers who sailed to the Americas in search of El Dorado never found the legendary 'City of Gold,' they did find in the Americas and elsewhere tremendous mineral wealth and lands to produce export crops including cotton, sugar, tea, coffee, and later, fruit. Five centuries later, mineral extraction and agribusiness continue to play important roles in North-South trade, with grave environmental consequences.

The mining industry vividly illustrates the global North's exploitation of the South as a source of natural wealth. When Papua New Guinea (PNG) was under Australian rule in the 1950s, for example, colonial administrators sold gold prospecting rights to multinational corporations without consulting the local communities who would be impacted. After PNG achieved independence in 1975, the national government persisted in encouraging mineral exploration to attract foreign direct investment. In one well-publicized case, an Australian-based firm opened the Ok Tedi gold-mining operation near the source of the Fly River. While some members of indigenous groups benefited from employment in the mines, toxic sediments killed off the river ecosystem's fish and birds, and devastated the livelihoods of the Yonggom people who live downstream. Yonggom activists successfully sued for compensation and damages to cover the rehabilitation of the river. The company, in turn, has threatened to close the mine, leaving the task of cleaning up to the PNG government (Kirsch 2002; Johnson and Jorgenson 1994).

The Costa Rican banana plantation economy exemplifies Northern exploitation of Southern environments through agribusiness. Taking advantage of government concessions for foreign direct investment, Standard Fruit Company cleared rain forests to make way for mono-crop banana cultivation, importing workers from surrounding regions and countries, and displacing traditional agroforestry producers. When bananas dropped in value on the world market, after 
years of high profits, the company scaled back production, leaving behind large tracts of destroyed forestlands and unemployed, landless workers (Vandemeer and Perfecto 1995).

\section{The South as 'Sink': Toxic Exports and the Dirty Industries}

In recent decades, rich countries increasingly have used poor countries a 'sink' for pollution and waste. Ironically, the enactment of stricter environmental standards in the global North sometimes has contributed to the growth of polluting industries and the dumping of toxic wastes in the South, as corporations and entire industries actively seek sites with fewer environmental regulations (Clapp 2001). ${ }^{2}$

One of the first cases to catch the attention of the international press came in the 1980s when Thor Chemicals, Inc., moved its mercury reclamation processing facility from the corporation's home in England to a village in South Africa's Kwazulu-Natal province, 40 miles north of Durban. After one year of operation, water samples in the village registered mercury levels over 1500 times the level permitted by the U.S. Environmental Protection Agency, and dangerous levels of mercury were detected in Durban's water supply as well (Lambrecht 1989; Fondaw 2001).

The infamous 'Summers memo' epitomizes the view of the South as sink. In February 1992, an internal memo by Lawrence Summers, the World Bank's chief economist at the time, discussed the transfer of pollution and dirty industries from industrialized countries to less-developed countries (LDCs). 'Just between you and me, shouldn't the World Bank be encouraging more migration of the dirty industries to the LDCs?' Summers wrote. He continued, 'I think the economic logic behind dumping a load of toxic waste in the lowest wage country is impeccable and we should face up to that.'(The Economist 1992) When the memo was leaked to the press, Summers claimed that his comments were intended simply to provoke debate within the World Bank. Given the reality of toxic dumping in South Africa and other poor countries, however, the memo seemed to confirm activists' fears about the indifference of many policymakers to international environmental inequalities.

\section{The South as 'Wilderness': Coercing Conservation}

A final dimension of international environmental inequalities arises when the global South is treated as a repository of 'wild Nature' that must be protected from local people. 'Coercive conservation' - preservation programs that ignore local people's traditional relationships with the land - arises from the Western (especially U.S.) wilderness ethic that places great value on untouched 'nature without people' (Peluso 1993).

In Africa, wildlife conservation programs dating from the colonial era have served as a means to control indigenous populations' use of the landscape (Ranger 1989). In the 1950s, for example, British colonial administrators resettled the Masai tribe, which has inhabited the savannas of what is now Kenya and Tanzania for some five hundred years, on smaller tracts of land in order to promote nature tourism. With limited access to traditional rangelands, the Masai now raise their herds in a degraded environment threatened by desertification (Neumann 1998). In recent decades, national and international conservation campaigns have further displaced Masai cattle- 
herders and other local people by banning them from nature preserves. While the park systems welcome foreign tourists on safari, they consider the local inhabitants who graze or hunt on the newly enclosed commons to be 'poachers' and punish them accordingly. By the early 1990s, armed rangers of the Kenyan Wildlife Service with had shot and killed over 100 people in efforts to protect the elephant, with support from the World Wildlife Fund (Peluso 1993). In many places, such coercive conservation policies have fostered a widespread perception that environmentalists care more about 'Nature' than they do about people.

\section{The Environment and Inequality within Countries}

Environmental injustice exists not only among nations, but within them as well. In rich countries and poor countries alike, certain populations often bear disproportionate burdens from the effects of environmental degradation. These environmental inequalities often follow lines of class, race, ethnicity, nationality, urban/rural divisions, age, and gender.

\section{Class}

For the reasons noted above environmental problems often affect most strongly the lives of poor and working people. Both individually and collectively, poor people have fewer political and material resources for avoiding environmental risks. In the 1984 Bhopal disaster in central India, for example, the vast majority of those who inhaled the toxic cloud released from the Union Carbide factory were poor workers who could not afford to live any place other than near the hazardous factory (Rajan 2001). With broken windows and inadequate ventilation, the houses of these slumdwellers offered little protection from the fumes (Centre for Science and Environment 1985). Poor communities often lack the political resources both to prevent the siting of hazards in their midst and to collect compensation for damages. Only six years after the Bhopal disaster, the state cut funding for long-term epidemiological research, leaving citizen's organizations to collect data on their own (Dhara 2002; Fortun 1998). Without adequate medical monitoring before as well as following after the chemical explosion, state bureaucrats frequently dismissed claims of disaster-related illness as 'compensation neurosis' or the consequence of 'normal' poor hygiene and nutrition (Rajan 2001).

\section{Race, Ethnicity, and Nationality}

In many places, racial, ethnic, and national minorities are especially vulnerable to pollution and environmental degradation. In the United States, for example, toxic waste sites are sited disproportionately near African-American communities (Bullard 1994), and migrant farmworkers, many of whom are Latinos, face chronic occupational exposures to pesticides (Pulido 1996). In metropolitan areas across the country, African-Americans, Latinos, and AsianAmericans tend to be concentrated in those neighborhoods most exposed to toxic industrial emissions (Ash and Fetter 2004; see also Pastor 2003). In Eastern Europe, where they were once forbidden to own land, the Roma (or Gypsies) today face housing discrimination, high unemployment, and dumping of toxic wastes in their villages and neighborhoods (Harper 1999). In southeast Asia, ethnic minorities find their livelihoods threatened by deforestation driven by powerful logging interests (Hurst 1990; Fahn 2003). In Nigeria, the Ogoni minority have seen 
their environment ravaged by multinational oil companies (Human Rights Watch 1999). The pattern is clear: political disenfranchisement translates into a precarious grip on environmental assets.

\section{Urban/Rural Divisions}

Environmental problems offen affect urban and rural people in different ways. Urban people typically face greater exposure to air pollution, particularly from mobile sources. In Budapest, Hungary, for example, pediatricians have recorded higher levels of lead in the blood of children living in the city center than in samples taken from suburban children (Harper 1999). In some of China's urban industrial centers, more than two-thirds of the children are afflicted with lead poisoning (Chu 2002).

Rural people, in contrast, often most suffer from the depletion of natural resources to meet urban demands, while receiving few of the infrastructural or other benefits of urban life. In some cases, the effects can be devastating. The lands of the Kayapo Indians in Brazil, for example, were flooded when the government dammed the Xingu River to generate electricity for urban populations (Turner 1993; Zimmerman et al. 2001). Native Americans living near nuclear test sites in Nevada, and people living near the Lop Nur atomic testing range in China, have suffered alike from their governments' perception of 'remote' rural areas as wastelands suitable for use as environmental sacrifice zones (Kuletz 1999; Johnston 1994).

\section{Age}

The elderly and the very young are especially vulnerable to environmental hazards, in part for physiological reasons and in part because they often spend their entire day within the same neighborhood. In West Harlem, New York, the elderly became key community organizers when air quality was threatened by a sewage treatment plant (Checker 2001). Children are especially prone to environmental risks because of their ongoing physical development. A recent World Health Organization $(1997,199)$ survey reported that 'two-thirds of the preventable diseases occurring worldwide from environmental causes occur among children' (see also Stephens 1996). Environmental groups focusing on children's health are flourishing across Eastern Europe and the former Soviet Union, from the Prague Mothers' struggle for clean air to the antinuclear activism of Ukraine’s 'Mama 86’ (Glazer and Glazer 1998).

\section{Gender}

Environmental degradation can affect men and women in different ways. Because labor is often divided on gender lines, men and women face different hazards both at work and at home. Women tend to be less mobile and hence more dependent on the immediate environment. In rural India, deforestation compels women to walk further than before in search of fuel wood; they are also exposed to high levels of hazardous indoor air pollutants from cooking fires (Agarwal 1986). ${ }^{3}$ At the same time, men often face disproportionate occupational exposures by virtue of employment in hazardous industries. 
In an extension of their traditional role as family caregivers, women often play a leading role in combating environmental health problems (Douglass et al. 2002). Penny Newman of the Center for Community Action and Environmental Justice in California characterizes the struggle against toxics in the United States as 'a movement of housewives,' because of the crucial role that mothers have played as grassroots community activists (Gottlieb 1993).

The various dimensions along which environmental inequalities are structured can overlap. In the Brazilian Amazon forest, for example, women rubber tappers have fought alongside men in demanding sustainable forest management and equitable access to resources. Women have been on the front lines of empates, the strike lines protecting stands of trees from clear-cutting. Led by the late Chico Mendes, the rubber tappers' union succeeded in establishing the Xapuri extractive reserve (see Hall 2003). To improve their access to markets where they could sell rubber, women decided to form the Women's Group of Xapuri, whose emergence highlights the cross-cutting elements of class, rural identity, and gender in the distribution and use of natural resources (Campbell 1996).

\section{Communities are Organizing for Environmental Justice}

Debunking the myth that only affluent citizens of the global North can afford to worry about the environment, poor communities across the globe are mobilizing to protect natural resources and environmental quality. In so doing, they assert their rights to clean air, water, and other openaccess resources that are 'available in theory to all, but available in practice only to those with the power to appropriate them' (Boyce 2003, 9). They thereby have increased the natural assets of low-income people, bringing benefits in the form of economic opportunities, improved public health, and greater social status. This section presents examples of grassroots activism by community-based organizations that form part of the growing global movement to redress environmental inequalities within and among countries.

\section{Fighting for Clean Air in Urban China}

The ten million people who live in Tianjin, China's third largest metropolis, are no strangers to smog. Sunlight filters on the northern port city through a blanket of brownish haze that is so thick it can be seen in satellite photos from space. Exhaust fumes and particulate matter choke the air and clog the residents' lungs as they ride their bicycles to work. After years of suffering from widespread respiratory illnesses, the residents of one Tianjin neighborhood joined together to prevent the expansion of a coal-burning plant that belched out foul-smelling smoke - and they won compensation for past damages as well as a promise that the company would adopt cleaner design in the new plant (Plafker 2002).

Like Tianjin, many Chinese cities are plagued by severe air pollution. Residents of Beijing call autumn the 'dirty season,' since it is marked by a sharp rise in the city's already elevated air pollution levels (China Economic Times 2001). Pollutants such as sulfur dioxide, lead, and particulate matter pose grave threats to health, especially for the children. For many years, pollution was widely regarded as the inevitable price to be paid for China's 'economic miracle.' 'The worst pollution is poverty,' state officials told a Western environmental consultant who 
visited the country in the early 1980s (Shen 2002, 26). Twenty years later, however, government officials and the public alike are increasingly aware of the costs of unregulated industrial growth. According to a report published by the Chinese government in 1999, the health costs of air and water pollution were over $\$ 46$ billion per year - equivalent to almost seven percent of the country's GNP (Pan 2001).

Today change is in the air in China, as heralded by a recent wave of citizens' class-action lawsuits against big polluters. The plaintiffs in Tianjin were represented by Wang Cangfa, an environmental lawyer who in 1998 founded the Center for Legal Assistance to Victims of Pollution (CLAPV). Staffed entirely by volunteers, CLAPV operates China's first environmental hotline, which receives more than 100 calls a month (Plafker 2002). The Center also offers workshops on environmental law for legal professionals and journalists, and provides free legal assistance to victims of air and water pollution. In another recent case, Wang Cangfa defended farmers from the outskirts of Beijing, whose livestock and produce were ruined by industrial effluents (Brettel 2002). The emerging Chinese environmental movement, including government-organized groups as well as non-governmental organizations, is bringing citizens' grievances to the attention of the courts and state environmental protection agencies (Knup 1997). China now faces the challenge of developing a more consistent environmental monitoring and enforcement system to enable the country to move beyond 'end-of-pipe' solutions and afterthe-fact compensation (Shen 2002).

\section{Asbestos Activism in South Africa}

In South Africa, mine workers and rural villagers are joining forces to fight the legacy of pollution from the asbestos industry. Since the fall of the apartheid regime in 1994, many asbestos mining corporations have pulled out of South Africa. Their mines and mills have closed, leaving thousands of workers unemployed. Although jobs have disappeared, the industry left behind all too visible scars on the landscape and on the bodies of those working in and living near the mines. Asbestos contamination has emerged as one of the country's major environmental health challenges. Defunct companies have left behind an estimated 121 mining sites that the South African government must now attempt to remediate and rehabilitate at great cost. In some places, winds have blown asbestos fibers as far as 100 kilometers from their source. Residents of villages near the former mines have found drifts of asbestos fibers in their gardens, playgrounds, and streets. Because villagers have constructed buildings from handmade bricks of mud and plaster, many homes and schools are contaminated. Asbestos-related diseases (ARDs) - a range of painful and deadly respiratory ailments including asbestosis, lung cancer, and mesothelioma - are common among former miners and mill workers, and also develop through prolonged, secondary exposure to asbestos tailings. In some villages near mines, more than one-third of the inhabitants suffer from ARDs (Jacobs et al. 2001).

In the Northern Cape and North-West provinces of South Africa, trade unions and village associations are organizing to clean up the pollution and address the health needs of people affected by ARDs. The National Union of Mineworkers is working in partnership with the Environmental Justice Networking Forum and local advocacy groups. They have used lobbying, litigation, advocacy, and education to advance their goals, pressing the South African government to take action and participating in the 1998 Parliamentary Asbestos Summit. In 
1999, a group of 7,500 South African miners and others afflicted with asbestosis filed suit in the United Kingdom against Cape Plc.; they won a settlement in June 2003, by which time 776 of the claimants had already died (Altenroxel 2003).

\section{Combating the Tragedy of the Corporate Commons in Russia's Far East}

On Sakhalin Island, in Russia's far east, activists are fighting to protect the Bering Sea's fisheries and wildlife from petroleum drilling. The residents of the island are a long way from Moscow, where government officials make decisions affecting their environment. Since the break-up of the Soviet Union, the Russian government has sought to attract foreign direct investment by licensing multinational corporations to conduct offshore oil exploration and drilling. Exxon is shifting operations from Alaska, with its stricter regulatory environment, to undertake large-scale exploration and drilling off Sakhalin (Carlton 2002). While Moscow gains income from the sale of licenses, the people of Sakhalin Island face the collapse of their local fishing and food processing industries (Barranikova and Lisitsyn 2001). Exxon and the Russian government promise that oil extraction exploration will create new jobs for local residents, but hopes for sustainable development through oil are not borne out by past experiences elsewhere (Wilson 1999).

Offshore oil exploration has had particularly dire consequences for the Nivkhi people, an indigenous group on the northern coast of Sakhalin Island whose traditional way of life is based on harvesting herring, smelt, salmon, and other fish of the Bering Sea. Since the collapse of the Soviet Union, the public transportation infrastructure of the island has fallen apart, further isolating the rural communities of the northern coast. But Nivkhi, along with other residents, find themselves more dependent than ever on the natural environment - fishing, hunting, and gathering for survival (Wilson 1999; Meier 2000). Nivkhi fishermen report that recent fish catches have been inedible, because of strong chemical odors and festering ulcers on the fish (Barranikova and Litsyn 2001).

Sakhalin Environmental Watch (SEW), a Russian non-governmental organization, is fighting to protect the island's natural resources and the rights of local people. SEW has organized a coalition that includes indigenous groups, representatives of the local fishing industry, and environmentalists (Boyd and Cook 1998/1999). Drawing on the local knowledge of Nivkhi fishermen, activists from SEW have conducted research on the state of fisheries near offshore oil exploration projects in the Bering Sea (Barranikova and Litsyn 2001). They also organized international exchanges with Alaskan communities affected by the 1989 Exxon Valdez oil spill, who offered testimony on its long-term ecological and economic damages (Steiner 1999). Yet SEW faces daunting challenges. After considerable progress in the 1990s toward building an environmental protection agency and encouraging growth of environmental organizations, Russian President Vladmir Putin has clamped down on environmentalists in the name of economic growth and national security (Cox 2000). The ability of non-governmental organizations like SEW to promote change depends, in part, on the presence of responsive government institutions, but in Russia the avenues for citizen participation in environmental decision-making remain quite limited. 


\section{Greening the Slums: Community Activism in Bangkok}

In recent decades, cities across Asia have been growing at a breakneck speed. As the center of Thailand's economic growth, metropolitan Bangkok has expanded rapidly since the 1960s. With economic growth and urbanization have come traffic congestion, air pollution, and high levels of lead and other toxins in the environment. Only two percent of the metropolitan population is linked to the municipal sewer system. A city built on rivers and canals, Bangkok now faces a shortage of potable water.

Although all Bangkok residents are affected by the city's environmental deterioration, poor communities suffer most acutely. Roughly one million the city's seven million residents live in slums, located mainly in marginal and industrial zones that are most vulnerable to floods, unmonitored trash disposal, and industrial waste discharges. Many of these settlements are 'illegal', being built on land owned by the city or by private firms, limiting the residents' political power to improve their living conditions (Douglass et al. 2002).

In one poor Bangkok community, however, residents have organized to improve the environment, expand small businesses, and provide badly needed social services. In 1990, residents of the Wat Chonglom squatter settlement initiated a community development program. The community began by cleaning up trash that had accumulated under buildings raised on stilts due to periodic flooding. Drawing on interest-free loans secured from Citibank by two professors at nearby Mahidol University, the residents connected houses to a piped water system, built a community hall and day-care center, and repaired and painted family homes. Women played an active role in setting the agenda and implementing these improvements. These community investments in turn fostered new opportunities, as residents opened food stalls, beauty parlors, video stores, and other small businesses. Can Wat Chonglom's successes be repeated in other communities? Answering with a qualified 'yes', a research team from the University of Hawai'i (Douglass et al. 2002) concludes that Wat Chonglom’s transformation was enabled by a combination of the community organization's partnership with a local university and access to external funds - social and economic assets that empowered residents to reappropriate assets in the urban environment.

\section{Central and Eastern Europe: The Struggle for Clean Water}

In Romania and Hungary, environmental organizations have been working for more than a decade to improve air and water quality. When a tailings dam breached at a gold-processing facility in Baia Mare, Romania, in January 2000, spilling roughly 100,000 cubic meters of water contaminated with cyanide and heavy metals into the Danube River system, thousands of citizens in both countries mobilized to defend their right to clean water and a safe environment. Within three days the toxic plume had flowed into Hungary, where it reached the Tisza River, a major tributary of the Danube, and in the next month the spill flowed down the Danube through Hungary, Serbia, Bulgaria, and back into Romania en route to the Black Sea. When the plume reached the Danube's delta at the Black Sea coast, a United Nations Environmental Program research team recorded cyanide at 0.058 milligrams per liter, almost six times the Romanian Environmental Protection Agency's permissible concentration level. All told, the disaster 
affected about two thousand kilometers of the Tisza and Danube Rivers. The cyanide killed fish, poisoned waterfowl, and threatened drinking water supplies.

The mining operation responsible for the spill, Aurul SA, was a joint venture begun in 1992 between a private Australian company, Esmeralda, and the state-owned Romanian mining concern, Remin. Ironically, the Romanian government had heralded Esmeralda's involvement as an opportunity to introduce more environmentally sound practices in the mining region. After the spill, the Romanian authorities levied only a paltry fine on Aurul SA, amounting to less than US\$200, because the owners were deemed to be in compliance with government standards.

In this respect, current Romanian policies share a curious commonality with those of the communist era, when officials accepted ecological degradation as an unfortunate but necessary side-effect of industrialization and growth. The president of a local environmental organization in Szolnok, a Hungarian city affected by the spill, characterizes Aurul SA as 'the perfect example of eco-colonialism,' explaining that foreign firms have taken advantage of unemployment and the lack of regulations (Harper and Ash 2001).

Rejecting the conventional wisdom that people must choose between jobs and the environment, communities in Romania and Hungary are rallying for sustainable livelihoods. In Baia Mare, the site of the spill, where life expectancies are ten years shorter than the Romanian national average and the World Health Organization has recorded some of the highest blood lead levels ever found, residents are literally fighting for their lives (Csagoly 2000). Members of the Baia Mare environmental organization ASSOC (Association of Professional NGOs for Social Assistance) point out that while mining and industrial operations contribute wages to the local economy, this comes at the expense of other producers whose livelihoods are damaged by polluted air, water, and soil. For example, farmers in and around Baia Mare cannot find markets for their contaminated produce, and residents cannot safely eat fruits and vegetables from their home gardens. ASSOC has been active in organizing public forums where farmers and other citizens present their grievances to local authorities, and following the cyanide spill the group initiated collaborative projects with Hungarian environmental groups downstream. Today they are coordinating a program that trains high-school science teachers throughout the region to monitor key environmental health indicators, and working with other organizations to rehabilitate water supplies and seek viable economic alternatives to the mining industry.

\section{Building Sustainable Forestry in Rural India}

In recent years, Joint Forest Management (JFM) programs in India have sought to involve forest communities in decision-making about subsistence use, commercial development, and afforestation (Mishra 1999). This represents a departure from traditional approaches to policing forests, which often resulted in violent conflict with local populations. These conflicts have their roots in the very purpose for which forest departments were created by the British colonial government in the nineteenth century: then, as now, the primary aim was to ensure a steady supply of timber to meet the demands of the state. The needs of local resource users were subordinated to this aim, and the state directed forestry departments to protect the forests from 'theft' by local people. ${ }^{4}$ 
The origins of JFM go back to 1972, when deforestation and demand by local communities for forest resources led to a government-initiated experiment in forest villages in the Midnapore district in West Bengal. Villagers were charged with protecting sal (Shorea robusta) trees, in return for which they received free usufructuary rights to non-timber forest products, a promise of a 25 percent share of the proceeds from sale of sal poles, and local employment. These innovations - combining the (re)appropriation and internalization routes to building natural assets - redefined poor communities not as part of the problem but instead as part of the solution. The success of this experiment led to more widespread advocacy of 'social forestry.' In the ensuing decades, the JFM model has spread to many states of the Indian union. These experiences have demonstrated the potential for forming less antagonistic relationships between local forest users and regulatory bodies. ${ }^{5}$

\section{Conclusion}

Around the world, social movements for environmental justice are helping to transform development policy. In the past, local people traditionally were cast in the role of 'users and choosers' of resource management plans drawn up in the offices of development agencies, an approach that failed to tap local knowledge, skills, and commitment to improving living conditions. In the community-based initiatives described here, people are 'makers and shapers' of efforts to protect and maintain healthy environments. ${ }^{6}$ Their struggles are premised on the belief that no landscape is a wasteland and no people are expendable.

The recurrent themes of rights and justice, both within and across national borders, point to a new conception of environmentalism that is gathering force across the world. Rather than a movement simply to protect the environment, we are witnessing the rise of movements to protect people by defending their rights to healthy environments and sustainable livelihoods based on access to natural assets. By rejecting false dichotomies between the well-being of Nature and the well-being of the world's poor, struggles for environmental justice reinvigorate the global quest for a sustainable future. 


\section{Endnotes}

${ }^{1}$ For an account of environmental injustice in the United States, see Pastor (2003).

${ }^{2}$ While the 1992 Basel Convention on the Control of Transboundary Movements of Hazardous Waste regulates the export of waste, its 'recycling' clause permits any toxic wastes labeled as recyclable material to be exported.

${ }^{3}$ Following pioneering research on the latter problem by epidemiologists and health workers, there is now a movement to improve the environmental quality of cookstoves (Kammen 1995).

${ }^{4}$ In adopting this philosophy, the Indian state followed traditions first established in France and Prussia (Rajan 1998, 2004). For parallels in Nepal and West Africa, respectively, see Jodha (2003) and Amanor (2003).

${ }^{5}$ For more on JFM, see Chambers et al. 1989, Gadgil and Guha 1995, Poffenberger and McGean 1996, Saxena 1997, Jefery and Sundar 1999, and People's Commission on Environment and Development in India 2004.

${ }^{6}$ On the contrast between 'users and choosers' versus 'makers and shapers', see Cornwall and Gaventa (2001). 


\section{Bibliography}

Agarwal, Bina (1986) Cold Hearths and Barren Slopes: Wood Fuel Crisis in the Third World. London: Zed Books.

Altenroxel, Lynne (2003) 'Pay-out for ill miners cut by half.' The Mercury (South Africa), 30 June.

Amanor, Kojo Sebastian (2003) 'Natural and Cultural Assets and Participatory Forest Management in West Africa.’ Paper presented at the International Conference on Natural Assets, Tagaytay City, Philippines, January. Available at http://www.umass.edu/peri/pdfs/WP75.pdf.

Ash and Fetter (2004) 'Who Lives on the Wrong Side of the Environmental Tracks? Evidence from the EPA’s Risk-Screening Environmental Indicators Model.' Social Science Quarterly 85(2): 441-462.

Barannikova, Natalia and Dmitri Lisitsyn (2001) 'Oil and Water Don't Mix’' Pacific Environments 2(3). Available at http://www.pacificenvironment.org/articles/oilandwater.htm.

Been, Vicki (1994) 'Locally Undesirable Land Uses in Minority Neighborhoods: Disproportionate Siting or Market Dynamics?’ Yale Law Journal 103: 1383-1422.

Boyce, James K. (2003) 'From Natural Resources to Natural Assets.' In Natural Assets: Democratizing Environmental Ownership, edited by James K. Boyce and Barry G. Shelley. Washington, D.C.: Island Press.

Boyce, James K. (2000) 'Let Them Eat Risk: Wealth, Rights, and Disaster Vulnerability.' Disasters 24(3): 254-261.

Boyd, Michelle, and Gary Cook (1998/1999) 'Whales of the Asian Pacific in Peril.' Earth Island Journal 14(1).

Brettell, Anna (2002) 'Environmental Disputes and Public Service Law: Past and Present.' China Environment Series 4: 66-69.

Bullard, Robert (1994) Unequal Protection: Environmental Justice and Communities of Color. San Francisco: Sierra Club.

Campbell, Connie, with the Women’s Group of Xapuri (1996) 'Out on the Front Lines But Still Struggling for Voice.’ In Feminist Political Ecology, edited by Dianne Rocheleau et al.. New York: Routledge.

Carlton, Jim (2002) 'In Russia with Fragile Ecology: Stymied in Alaska, Oil Companies Find Russian Rules Aren’t as Strict.’ Wall Street Journal 4 September, A1. 
Chambers, R., N.C. Saxena, and T. Shah (1989) To the Hands of the Poor: Water and Trees. New Delhi: Oxford.

Checker, Melissa (2001) 'Like Nixon Coming to China: Finding Common Ground in a MultiEthnic Coalition for Environmental Justice.’ Anthropological Quarterly 74(3): 135-146.

China Economic Times (2001) 24 October.

Chu, Henry (2002) 'China Is Passing Pollution to a New Generation, Study Finds.' Los Angeles Times 19 June, A3.

Clapp, Jennifer (2001) Toxic Exports: The Transfer of Hazardous Wastes from Rich to Poor Countries. Ithaca, N.Y.: Cornell University Press.

Cornwall, Andrea and John Gaventa (2001) 'From Users and Choosers to Makers and Shapers: Repositioning Participation in Social Policy.' Institute for Development Studies Working Paper \# 127. Sussex, UK: Institute for Development Studies.

Cox, Rory (2000) ‘Putin Sets Back Ecological Clock.’ Pacific Environments 2(2).

Csagoly, Paul (2000) ‘After the Tisza Disaster.’ The Bulletin 9(3): 9-11.

Centre for Science and the Environment (1985) The State of India's Environment, 1984-5: The Second Citizen's Report. New Delhi: CSE.

Dhara, V. Ramana (2002) 'What Ails the Bhopal Disaster Investigations? (And is there a Cure?).’ International Journal of Occupational and Environmental Health 8: 371-79.

Douglass, Mike, et al. (2002) 'Urban Poverty and the Environment: Social Capital and StateCommunity Synergy in Seoul and Bangkok.' In Livable Cities: Urban Struggles for Livelihood and Sustainability, edited by Peter Evans. Berkeley: University of California.

The Economist (1992) 'Pollution and the poor: Lawrence Summers' memo,' The Economist 8 February, p.66.

Fahn, James (2003) A Land on Fire: The Environmental Consequences of the Southeast Asian Boom. Boulder: Westview.

Fondaw, Corey (2001) 'Thor Chemicals and Mercury Exposure in Cato-Ridge, South Africa.' University of Michigan Environmental Justice Case Studies. (Available at http://www.umich.edu/ snre492/Jones/thorchem.htm.)

Fortun, Kim (1998) 'The Bhopal Disaster: Advocacy and Expertise.' Science as Culture 7(2): 193-216. 
Gadgil, Madhav, and Ramachandra Guha (1995) Ecology and Equity: The Use and Abuse of Nature in Contemporary India. New York: Routledge.

Glazer, Penina Migdal and Myron Peretz Glazer (1998) The Environmental Crusaders :

Confronting Disaster and Mobilizing Community. University Park, PA: Pennsylvania State.

Gottlieb, Robert (1993) Forcing the Spring: The Transformation of the American Environmental Movement. Washington, DC: Island Press.

Hall, Anthony (2003) 'Extractive Reserves: Building Natural Assets in the Brazilian Amazon.' Paper presented at the International Conference on Natural Assets, Tagaytay City, Philippines, January. Available at http://www.umass.edu/peri/pdfs/CDP6.pdf.

Harper, Krista (1999) 'From Green Dissidents to Green Skeptics: Environmental Activists and Post-Socialist Political Ecology in Hungary.' PhD dissertation. University of California, Santa Cruz.

Harper, Krista, and Michael Ash (2001) ‘The Tisza Chemical Spill.’ In History in Dispute 7: Water and the Environment Since 1945: Global Perspectives., edited by Char Miller et al.. Columbia, S.C.: Manly.

Human Rights Watch (1999) 'The Price of Oil: Corporate Responsibility and Human Rights Violations in Nigeria’s Oil Producing Communities: January.’ Available at http://www.hrw.org/reports/1999/nigeria.

Hurst, Philip (1990) Rainforest Politics: Ecological Destruction in South-East Asia. London: Zed Books.

Jacobs, Nancy, et al. (2001) 'Asbestos-Related Disease in South Africa: Opportunities and Challenges Remaining Since the 1998 Parliamentary Asbestos Summit.’ A report presented to South Africa's Parliamentary Portfolio, Committee on Environmental Affairs Tourism, 12 October 2001.

Jeffery, R. and N. Sundar (1999) Editors. A New Moral Economy for India's Forests?: Discourses of Community and Participation. New Delhi: Sage.

Jodha, N.S. (2003) 'Natural Resource Management and Poverty Alleviation in Mountain Areas.' Paper presented at the International Conference on Natural Assets, Tagaytay City, Philippines, January. Available at http://www.umass.edu/peri/pdfs/CDP11.pdf.

Johnston, Barbara Rose (1994) 'Experimenting on Human Subjects: Nuclear Weapons Testing and Human Rights Abuse.' In Who Pays the Price? The Sociocultural Context of Environmental Crisis, edited by Barbara Rose Johnston. Covelo, CA: Island.

Johnston, Barbara Rose, and Daniel Jorgensen (1994) 'Mineral Development, the Environment, and Human Rights: The Ok Tedi Mine, Papua New Guinea.' In Who Pays the Price? The 
Sociocultural Context of Environmental Crisis, edited by Barbara Rose Johnston. Covelo, CA: Island.

Kammen, Daniel M. (1995) 'Cookstoves for the Developing World.' Scientific American 273(1): 72-6.

Kirsch, Stuart (2002) 'Anthropology and Advocacy: A Case Study of the Campaign against the Ok Tedi Mine.' Critique of Anthropology 22(2): 175-200.

Knup, Elizabeth (1997) 'Environmental NGOs in China: An Overview.' China Environment Series 1: 9-15.

Kuletz, Valerie (1999) The Tainted Desert. New York: Routledge.

Lambrecht, Bill (1989) 'Waste Pollutes Drinking Water in South Africa.' St. Louis PostDispatch. 26 November.

Meier, Andrew (2000) 'Pollution on Sakhalin: Man’s Gain May Be Nature’s Loss.' Time Europe 156(19): 6.

Mishra, T. R. (1999) 'Forestry Research in India.’ Economic and Political Weekly. April 17-24.

Neumann, Roderick P. (1998) Imposing Wilderness: Struggles over Livelihood and Nature Preservation in Africa. California: University of California Press.

Pan, Philip P. (2001) 'Cancer-Stricken Chinese Village Tries to Pierce a Wall of Silence.' Washington Post. 5 November, A19.

Pastor, Manuel (2003) 'Environmental Justice: Reflections from the United States.' Paper presented at the International Conference on Natural Assets, Tagaytay City, Philippines, January. Available at http://www.umass.edu/peri/pdfs/CDP1.pdf.

People's Commission on Environment and Development in India (2004) 'Vanishing Forests.' Available at http://www.pcedindia.com/peoplescomm/forest_4a.htm.

Peluso, Nancy (1993) 'Coercing Conservation: The Politics of State Resource Control.' Global Environmental Change 3(2).

Plafker, Ted (2002) 'Chinese activists take to the courts.' International Herald Tribune, 28 August.

Poffenberger, Mark, and Betsy McGean (1996) Editors. Village voices, forest choices: joint forest management in India. Delhi: Oxford University Press.

Pulido, Laura (1996) Environmentalism and Economic Justice: Two Chicano Struggles in the Southwest. Tucson, AZ: Arizona. 
Rajan, Ravi (1998) 'Imperial Environmentalism or Environmental Imperialism?:

European Forestry, Colonial Foresters, and the Agendas of Forest Management in British India 1800-1900.' In Nature and the Orient, edited by R. Grove, V. Damodaran and S. Sangwan. Delhi: Oxford University Press.

Rajan, Ravi (2004) Modernizing Nature: Tropical Forestry and the Contested Legacy of British Colonial Eco-development, 1800 - 2000. Oxford: Oxford University Press.

Rajan, S.R. (2001) 'Toward a Metaphysic of Environmental Violence: The Case of the Bhopal Gas Disaster.' In Violent Environments, edited by Nancy Lee Peluso and Michael Watts. Ithaca, NY: Cornell.

Ranger, Terrence (1989) 'Whose Heritage? The Case of the Matopo National Park.' Journal of Southern African Studies 15(2): 217-49.

Saxena, N.C. (1997) The Saga of Participatory Forest Management in India. Jakarta: CIFOR.

Shen, Thomas T. (2002) 'Concept and Policies for Preventing Pollution and Poverty in China.' Sinosphere 4(1): 25-8.

Steiner, Rick (1999) 'Oil Spills: Lessons from Alaska for Sakhalin.' Economic Development and the Environment on the Sakhalin Offshore Oil and Gas Fields II. Hokkaido, Japan: Hokkaido University Slavic Research Center. Available at http://srch.slav.hokudai.ac.jp/sakhalin/eng/71/contents.html.

Stephens, Sharon (1996) 'Reflections on Environmental Justice: Children as Victims and Actors.’ Social Justice 23(4): 62.

Turner, Terrence (1993) 'The Role of Indigenous Peoples in the Environmental Crisis: The Example of the Kayapo of the Brazilian Amazon.' Perspectives in Biology and Medicine 36(3): 526.

Vandermeer, John, and Yvette Perfecto (1995) Breakfast of Biodiversity: The Truth about Rainforest Destruction. Oakland, CA: Food First.

Wilson, Emma (1999) 'Conflict or Compromise? Traditional Natural Resource Use and Oil Exploitation in Northeastern Sakhalin/Noglikskii District.' Economic Development and the Environment on the Sakhalin Offshore Oil and Gas Fields II. Hokkaido, Japan: Hokkaido University Slavic Research Center. Available at http://srch.slav.hokudai.ac.jp/sakhalin/eng/71/contents.html.

World Health Organization (1997) Health and Environment in Sustainable Development: Five Years after the Earth Summit. Geneva: WHO. 
Zimmerman, Barbara, et al. (2001) 'Conservation and Development Alliances with the Kayapó of South-Eastern Amazonia, a Tropical Forest Indigenous People.' Environmental Conservation 28(1): 10-22. 